\title{
PERLINDUNGAN HUKUM TERHADAP WISATAWAN PASCA BERLAKUNYA PERATURAN DAERAH PROPINSI BALI NO.2 TAHUN 2012
}

\author{
I Ketut Subadra \\ Fakultas Ilmu Sosial dan Ilmu Politik Universitas Mahendradatta - Denpasar \\ e-mail : info@grahaadventure.com
}

\begin{abstract}
Abstrak - Di era globalisasi dan ditengah semakin meningkatnya kuantitas kepariwisataan Bali, kerap kali menimbulkan berbagai permasalahan baru yang menuntut adanya peningkatan kualitas layanan dan perlindungan hukum bagi setiap wisatawan. Pemerintah daerah bersama stake holder terkait yang terlibat dalam kegiatan kepariwisataan ini dituntut bekerja keras agar selalu meningkatkan perlindungan hukum terhadap setiap wisatawan agar kepariwisataan budaya Baliyang diprogramkan pemerintah Bersama masyarakat dapat berjalan secara berkelanjutan.

Pasca berlakunya Peraturan Daerah Propinsi Bali No.2 Tahun 2012 merupakan aspek legalitas dari penyelenggara kekuasaan untuk mencapai tujuanitu. Penyelenggara kekuasaan dimaksud terdiri dari alat - alat kekuasaan atau perlengkapan negara sebagai unsur penyelenggara pemerintahan dari pusat sampai di daerah. Penyelenggaraan pemerintahan dianggap selalu dinamis atau bergerak (de staat in bweging). Unsur penyelenggara kekuasaandi daerah terutama dalam melaksanakan kekuasaan terkait kepariwisataan budaya Bali. Penyelenggaraan inidilaksanakan melalui para pejabat aparaturnya yang diberikan kewenangan untuk menyelenggarakan pemerintahan di daerah. Hal ini pula diberikan untuk melakukan tindakan perlindungan terhadap wisatawan yang berkunjung pada masing - masing destinasi pariwisata.

Perlindungan hukum harus dilakukan secara berkeadilan dan memberikan kesejahteraan hidup terhadap setiap wisatawan. Inilah dasar dikeluarkannya Peraturan Daerah Propinsi Bali No.2 Tahun 2012 tentang Kepariwisataan Budaya Bali. Terbentuknya peraturan daerah Bali ini adalah terdapatnya perlindungan hukum berupa kepastian dan jaminan kesejahteraan wisatawan serta diperolehnya rasa aman dan nyaman melalui suatu pelayanan yang berkualitas (service quality).
\end{abstract}

Kata Kunci: perlindungan hukum, wisatawan, kepariwisataan budaya Bali

Abstract - In the era of globalization and amid the increasing quantity of tourism in Bali, it often creates a variety of new problems that require an increase in the quality of services and legal protection for every tourist. The local governments together with related stakeholders who are involved in tourism activities are required to work hard to always improve legal protection for every tourist so that Balinese cultural tourism programmed by the government Together with the community can run sustainably.

After the enactment of Bali Province Regional Regulation No. 2 of 2012 is a legal aspect of the organizer of power to achieve that goal. The organizer of the said power consists of instruments of power or equipment of the state as elements of government administration from the center to the regions. The administration of government is deemed to be always dynamic or moving (de staat in bweging). Elements of the organizers of power in the regions, especially in exercising power related to Balinese cultural tourism. This implementation is carried out through officials who are given the authority to organize government in the region. It is also given to take action to protect tourists visiting each tourism destination.

Legal protection must be carried out in an equitable manner and provide welfare for every tourist. This is the basis for the issuance of Bali Province Regional Regulation No.2 of 2012 concerning Bali Cultural Tourism. The establishment of this Bali regulation is the existence of legal protection in the form of certainty and guarantee of tourist welfare and obtaining a sense of security and comfort through a service quality.

Keywords: legal protection, tourists, Balinese cultural tourism 


\section{PENDAHULUAN}

\subsection{Latar Belakang}

Konsekuensi suatu negara hukum adalah menempatkan hukum di atas segala kehidupan berbangsa dan bernegara. Negara dan masyarakat diatur dan diharuskan tunduk pada hukum, bukan tunduk pada orang lain. Aspek hukum berada diatas segalanya, kekuasaan dan penguasa tunduk kepada aturan - aturan hukum. Hubungan yang menimbulkan hak dan kewajiban telah diatur dalam peraturan hukum yang dikenal dengan sebutan hubungan hukum. Hukumharus mampu memayungi berbagai kepentinganmasyarakat, sehingga benturan kepentingan dalam kehidupan bermasyarakat dapat dihindari atau sedapat mungkin ditiadakan.Perlindungan hukum terhadapsuatukepentingantertentu, dapat dilakukan dengan cara membatasi kepentingan pihak lain. Perlindungan hukum bagi setiap warga negara Indonesia tanpa terkecuali, dapat ditemukan dalam UUD Republik Indonesia 1945.

Setiap produk hukum yang dihasilkan oleh penyelenggara pemerintahan atau legislatif harus senantiasa dapat memberikan jaminan perlindungan hukum, bahkan harus mampu memberikan rasa keadilan bagi semua orang. Menurut Hetty Hasanah (2004), mengatakan bahwa perlindungan hukum merupakan segala upaya yang dapat menjamin adanya kepastian hukum, sehingga dapat memberikan perlindungan hukum kepada pihak-pihak yang bersangkutan atau yang melakukan tindakan hukum.

Di era globalisasi tuntutan perlindungan dan jaminan hak asasi manusia semakin mengedepan. Hal tersebut berkaitan dengan kekuasaan, kekuatan sosial, dan struktur sosial yang ada. Suparman Khan (2001) mengatakan bahwa sebagai negara demokrasi,dimana kedaulatan ada di tangan rakyat, partisipasi rakyat sangat diperlukan. Rakyatlah sebagai penentu terwujudnya jaminan pelaksanaan perlindungan hak asasi ini.Perlindungan terhadap potensiwisata yang adaharus dapat dipertahankan, karena obyek wisata merupakan ciri khas suatu negara.

Pengembangan faktor penunjang dalam pembangunan sektor pariwisata juga harus diperhatikan dan dijaga eksistensinya,sehingga dalam percaturan industri kepariwasataandapat bersaing.Pariwisata merupakansebuah industri yang unik dan memiliki ciri khasyaitu nilai-nilai tradisi budaya dan obyek-obyek pariwisata yang khas/unik. Dalamlingkup nasional, sektor pariwisata dianggap sebagai sektor yang potensial dimasa yang akan datang.

Menurut analisis World Travel and Tourism Council (WTTC) dalam Oka Yoeti (2009) bahwa industri pariwisata menyumbang sampai 9,1\% dari produk domestik bruto (PDB) Indonesia.Hal ini harus disikapi oleh pemerintah daerah untuk meningkatkan potensi wisata agar dapat dijadikan sebagai sarana guna meningkatkan pendapatan asli daerah.

Menurut Hadion Wijoyo (2006) bahwa sumber pendapatan asli daerah sendiri merupakan sumber keuangan daerah yang digali dari dalam wilayah daerah bersangkutan yang dapat berupa hasil pajak daerah, hasil retribusi daerah, hasil pengelolaan kekayaan daerah. Berlakunya undang-undang otonomi daerah mengakibatkan pemerintah daerah dituntut untuk menggali sumber pendapatan asli daerah yang sebesar - besarnya, karena tidak mungkin terus menggantungkan bantuan dari pusat saja untuk membiayai suatu pembangunan.

Di era otonomi daerah,pemerintah daerah memiliki otonomi penuh mengurus urusan rumah tangganya sendiri. Urusan yang tetap menjadi wewenang penuh pemerintah pusat hanya meliputi urusan keimigrasian, moneter, pertahanan, keamanan, peradilan dan sebagian pendidikan masih ditangan pemerintah pusat, meskipun pelaksanaannya oleh pemerintah daerah.

Pembangunan kepariwisataan tidak terlepas dari kemampuan daerah mengelola potensi yang ada, didukung oleh pengetahuan dan keterampilan sumber daya manusia yang ada serta peran serta masyarakat dalam iklim keterbukaan dan demokratisasi. Implementasi otonomi daerah mengakibatkan pembangunan di sektor pariwisata yang meliputi pembiayaan, perizinan, perencanaan dan evaluasi menjadi kewenangan pemerintah daerah untuk menyelenggarakannya. Daerah dituntut lebih mandiri dalam mengembangkan obyek dan potensi wisatanya.

Perlindungan hukum terhadap wisatawan dan para pengusaha pariwisata sangat diperlukan, sehinggapembangunan di 
sektor kepariwisataan dapat terlindungi. Implementasi otonomi daerah harus dapat memacu daerah menggali berbagai macam potensi yang ada di daerah, serta menjamin terwujudnya pembangunan kepariwisataan budaya Bali yang berkelanjutan. Berkaitan dengan kepariwisataan, telah hadirUndang-Undang No. 10 Tahun 2009 Tentang Kepariwisataan. Undang-undang ini dilatarbelakangi: pertama, keadaan alam, flora, dan fauna, sebagai karunia Tuhan Yang Maha Esa, serta peninggalan purbakala,peninggalan sejarah, seni dan budaya yang dimiliki bangsa Indonesia merupakan sumber daya dan modal pembangunan kepariwisataan untuk peningkatan kemakmuran dan kesejahteraan rakyat sebagaimana terkandung dalam Pancasila dan Pembukaan UUDRepublik Indonesia 1945; kedua, kebebasan melakukan perjalanan dan memanfaatkan waktu luang dalam wujud berwisata merupakan bagian dari hak asasi manusia; ketiga, kepariwisataan merupakan bagian integral dari pembangunan nasional yang dilakukan secara sistematis, terencana,terpadu, berkelanjutan dan bertanggung jawab dengan tetap memberikan perlindungan terhadap nilai-nilai agama, budaya yang hidup dalam masyarakat, kelestarian dan mutu lingkungan hidup serta kepentingan nasional; dan keempat, pembangunan kepariwisataan diperlukan untuk mendorong pemerataan kesempatan berusaha dan memperoleh manfaat serta mampu menghadapi tantangan perubahan kehidupan lokal, nasional, dan global.

Undang - Undng No. 10 Tahun 2009 Tentang Kepariwisataan ini telah diikuti dengan dikeluarkannya Peraturan Daerah Propinsi Bali No.2 Tahun 2012 Tentang Kepariwisataan Budaya Bali yang sesuai dengan kultur dan tuntutan perkembangan kepariwisataan Bali saat ini. Wisata menurut Pasal 1ayat (8) Perda Bali No. 2 Tahun 2012ini diartikan sebagai kegiatan perjalanan yang dilakukan oleh seseorang atau sekelompok orang dengan mengunjungi tempat tertentu untuk tujuan rekreasi, pengembangan pribadi atau mempelajari keunikan daya tarik wisata yang dikunjungi dalam jangka waktu sementara. Sedangkan Pasal 1 ayat (9) Perda Bali No. 2 Tahun 2012 menyebutkan bahwa pariwisata merupakan berbagai macam kegiatan wisata dan didukung berbagai fasilitas serta layanan yang disediakan oleh masyarakat, pengusaha, pemerintah, dan pemerintah daerah. Orang yang melakukan wisata kemudian disebut sebagai wisatawan.

Pembangunan kepariwisataan mesti diselenggarakan berdasarkan pada beberapa prinsip guna menjunjung tinggi norma agama dan nilai budaya serta harus mengatur hak dan kewajiban para wisatawan dan pengusaha pariwisata. Di era globalisasi saat ini mengakibatkan semakin meningkatnya kuantitas kepariwisataan Bali sehingga kerap kali menimbulkan berbagai permasalahan baru yang menuntut adanya peningkatan kualitas layanan dan perlindungan hukum bagi para wisatawan. Pemerintah daerah bersama para stake holder terkait yang terlibat dalam pembangunan kepariwisataan ini dituntut bekerja keras untuk meningkatkan perlindungan hukum terhadap setiap wisatawan agar kepariwisataan budaya Bali dapat berjalan secara berkelanjutan.

Pasca berlakunya Peraturan Daerah Propinsi Bali No.2 Tahun 2012 yang merupakan peraturan kekuasaan untuk mencapai tujuan itudimaksudkan sebagai alat kekuasaan atau perlengkapan negara disamping sebagai unsur penyelenggara pemerintahan di daerah. Penyelenggaraan pemerintahan selalu dinamis (de staat in bweging) karena mengikuti gerak kehidupan masyarakatnya. Unsur penyelenggara kekuasan daerah ini diberikan kewenangan terkait kepariwisataan budaya Bali untuk melakukan tindakan perlindungan terhadap wisatawan.

Perlindungan hukum yang dilakukan terhadap para wisatawan oleh penyelenggara pemerintahan daerah bersama para stake holderdimaksudkan agar setiap wisatawan mendapatkan rasa aman dan nyaman selama melakukan kunjungan di beberapa destinasi pariwisata. Hal ini tentu dengan harapan agar apa yang menjadi tujuan kepariwisataan dapat tercapai dengan lebih mudah. Perlindungan hukum harus dilakukan secara berkeadilan dan memberikan kesejahteraan hiduppada setiap orang.

Melalui peraturan daerah ini setiap wisatawan yang datang berkunjung ke tempat destinasi wisata agar memperoleh perlindungan hukum terutama terkait dengan kepastian dan jaminan kesejahteraan 
serta rasa aman dan nyaman melalui suatu pelayanan yang berkualitas. Kualitas layanan merupakan standar layanan guna meningkatkan pendapatan usaha disamping terjaminnya pembangunan kepariwisataan budaya Bali yang berkelanjutan (Bali sustainable culture tourism).

Bertitik tolak dari permasalahan diatas dapat ditarik beberapa rumusan permasalahan, sebagai berikut diantaranya: bagaimanakah konsep perlindungan hukum bagi wisatawan, bagaimanakah prinsip - prinsip perlindungan hukum terhadap wisatawan dan apakah hak dan kewajiban wisatawanpasca berlakunya Peraturan Daerah Propinsi Bali No.2 Tahun 2012.

\section{PEMBAHASAN}

\subsection{Konsep Perlindungan Hukum Ter- hadap Wisatawan}

Di era globalisasi setiap pengusaha pariwisata harus mampu menghasilkan produk pariwisata atau jasa yang berkualitas guna memberikan kepastian serta meningkatkan kesejahteraan masyarakat. Semakin terbukanya demandakibat dari proses globalisasi ini juga menuntut adanya peningkatan kesadaran, pengetahuan, kepedulian serta kemampuan setiap individu dalam sektor kepariwisataan.

Dewasa ini setiap daerah, tak terkecuali Bali berusaha menyediakan sarana dan prasarana pariwisata yang berkualitas. Akan tetapi usaha tersebut tidak akan ada artinya apabila suatu daerah tidak dapat menciptakan rasa aman dan nyaman bagi para wisatawan sebagai konsumennya. Menurut Violetta Simatupang (2009) bahwa ketidakamanan dan ketidaknyamanan para wisatawan dapat diartikan bahwa hak mereka sebagai wisatawan tidak terlindungi di tempat yang mereka kunjungi.

Bali sebagai bagian dari Indonesia yang merupakan negara berdasarkan hukum, hal tersebut tertuang dalam Undang - Undang Dasar Pasal 1 ayat (3) UUD Republik Indonesia 1945 yang menyatakan negara Indonesia adalah negara hukum. Tujuan pokok hukum menurut Sudikno Mertokusumo (2005) adalah menciptakan tatanan masyarakat yang tertib, menciptakan ketertiban dan keseimbangan. Dengan tercapainya ketertiban di dalam masyarakat diharapkan kepetingan masyarakat akan terlindungi.
Hukum dapat mengatur tingkah laku semua orang saat mereka beraktifitas dan berinteraksi dengan orang lain. Dalam pembangunan kepariwisataan misalnya, hukum dapat dijadikan acuan bertindak dan berbuat oleh pengusaha pariwisata agar setiap tindakan dan perbuatannya dapat memberikan rasa keamanan dan kenyamanan pada setiap wisatawan. Penerapan hukum terhadap wisatawan merupakan salah satu usaha untuk menciptakan tata tertib, keamanan dan ketentraman dalam pembangunan kepariwisataan sebagai pencegahan terjadinya pelanggaran hukum.

Perlindungan hukum dan keamanan serta kenyamanan terhadap wisatawan yang berkunjung ke suatu destinasi pariwisata sangat besar pengaruhnya bagi pertumbuhan dan perkembangan pariwisata Bali. Perlindungan hukum dan keamanan terhadap wisatawan menjadi sangat penting, mengingat banyak wisatawan yangmengalami peristiwa pencurian, penipuan dan tindakan-tindakan kriminal lainnya yang merugikan diri wisatawan.

Selain itu, tidak jarang ada pengusaha pariwisata sendiri yang menjalankan kegiatannya tidak memperhatikan keselamatan dan keamanan wisatawan. Banyak kejadian atau peristiwa yang menimpa para wisatawan, misalnya kecelakaan yang terjadi di tempat - tempat destinasi wisata yang merugikan wisatawan. Atas kejadian tersebut, sudah barang tentu perlu diperhatikan hal yang menyangkut perlindungan hukum terhadap keamanan wisatawan. Hal ini dilakukan karena adanya berbagai tantangan dalam pembangunan kepariwisataan di Bali saat ini.

Mardani (2003) menyatakan, bahwa pariwisata berjalan tanpa henti dengan berbagai perubahan yang juga tanpa henti. Peluangdan tantangan silih berganti. Para investor atau pengusaha pariwisata dengan aktifitasnya dibidang usaha pariwisata masih menaruh perhatian tinggi dalam konteks pembangunan pariwisata.Pentingnya peranan pariwisata dalam pembangunan ekonomi diberbagai negara sudah tidakdiragukan lagi.

Pitana dan Surya Diarta (2009:2) menyebutkan bahwa banyak negara sejak beberapa tahun terakhir menggarap pariwisata dengan serius dan menjadikan pariwisata sebagai sektor perolehan kerja 
maupun pengentasan kemiskinan.Pariwisata merupakan salahsatu devisa negara yang sangat besarpemasukannya dan mempunyai andil besardalam membangun perekonomian yang saat ini pertumbuhannya masih sangatlambat. Sektorpariwisata di Indonesia masih bisa di kembangkan dengan lebihmaksimal.

Pengembangan sektor pariwisata yang dilakukan dengan baik akanmampu menarik wisatawan domestikmaupun wisatawan asing untuk datang danmembelanjakan uangnya.Dari transaksi itulahmasyarakat daerah wisata akan terangkat taraf hidupnya serta negara akanmendapat devisa dari wisatawan asing yang menukar mata uang negaranyadengan rupiah.

Dalam konteks perlindungan hukum wisatawan, yang perlu dilindungiadalah hak-hak wisatawan. Setiap wisatawan memiliki hak atas kenyamanan, keamanan serta mendapatkan perlakuan yang adil dan pelayanan yang sebaik-baiknya dari negara dimana yang bersangkutan mengunjungi tempat wisata. Negara dimana wisatawan berkunjung wajib menyediakan keamanan dan keselamatan berdasarkan peraturan perundang-undangan yang ada.

Pengaturan perlindungan hukum terhadap wisatawan didalam peraturan perundang-undangan semestinya diatur secara jelas dan tegas dalam rangka menjamin adanya kepastian hukum. Penelusuran terhadap Undang- Undang No. 10 Tahun 2009 Tentang Kepariwisataan, UndangUndang No. 8 Tahun 1999 Tentang Perlindungan Konsumen dan Peraturan Daerah Propinsi Bali No.2 Tahun 2012 Tentang Kepariwisataan Budaya Bali, perlu dilakukan guna mengetahui ada dan tidaknya aspek perlindungan hukum terhadap wisatawan.

Dalam kaitannya dengan uraian tersebut di atas Pasal 4 UU No. 10 Tahun 2009 telah menjelaskan bahwa tujuan dikembangkannya kepariwisataan adalah dalam rangka meningkatkan pertumbuhan ekonomi, meningkatkan kesejahteraan rakyat, menghapus kemiskinan, mengatasipengangguran, melestarikan alam lingkungan dan sumber daya, memajukan kebudayaan, mengangkat citra bangsa, memupuk rasa cinta tanah air, memperkukuh jati diri dan kesatuan bangsa dan mempereratpersahabatan antarbangsa.
Para pemangku kepentingan di Indonesia dan khususnya para pembuat kebijakan, harus terlibat aktif dalam proses penyusunan kesepakatan-kesepakatan internasional di bidang kepariwisataankarena mungkin saja di dalamnya ada aturan main yang tidak sesuai dengan prinsip-prinsip nasional yangtelah ditetapkan dalam penyelenggaraan kepariwisataan. Perlindungan hukum terhadap wisatawan harus ditegakkan agar perlindungan terhadap hak-hak wisatawan yang sedang menikmati perjalanan wisatanya mendapatkan rasa keamanan dan kenyamanan.

\subsection{Prinsip-Prinsip Perlindungan $\mathrm{Hu}-$ kum}

Perlindungan hukum merupakan skripsi dari bekerjanya fungsi hukum untuk mewujudkan tujuan-tujuan hukum yakni keadilan, kemanfaatan dan kepastian hukum. Wahyu Sasongko (2007) mengatakan bahwa perlindungan hukum dapat diartikan sebagai perlindungan oleh hukum atau perlindungan dengan menggunakan pranata dan saranahukum.

Perlindungan hukum adalah suatu perlindungan yang diberikan kepada setiap orang sesuai dengan aturan hukum, baik aturan itu yang bersifat preventifmaupun bersifat represif, baik secara tertulis maupun tidak tertulis dalam rangka penegakan peraturanhukum. Setiap orang mesti mendapatkan perlakuan yang sama tanpa memandang tinggi rendahnya status maupun kedudukannya. Setiap orang dipandang sama di mata hukum (equlity before the law).

Secara Konseptual, perlindungan hukum yang diberikan bagi para wisatawan yang melakukan aktifitas di destinasi pariwisata merupakan implementasi atas adanya prinsip pengakuan dan perlindungan terhadap harkat dan martabat wisatawan yang bersumber pada prinsip negara hukum. Wisatawan yang datang ke suatu destinasi wisata sebagai konsumen dari pengusaha pariwisata menurut Undang Undang No.10 Tahun 2009 Tentang Kepariwisataan, Undang- Undang No. 8 Tahun 1999 Tentang Perlindungan Konsumen dan Peraturan Daerah Propinsi Bali No.2 Tahun 2012 Tentang Kepariwisataan Budaya Bali, harus mendapatkan perlindungan secara berkeadilan agar memperoleh rasa aman dan nyaman bagi setiap wisata- 
wan.

Danang Sunyoto $(2015 ; 142)$ menyebutkan bahwa ada tiga prinsip perlindungan konsumen, yaitu: prinsip bertanggung jawab berdasarkan kelalaian, prinsip tanggung jawab berdasarkan wanprestasi dan prinsip tanggung jawab mutlak.

1. Prinsip Bertanggung Jawab Berdasarkan Kelalaian

Disebutkan bahwa tanggung jawab kelalaian adalah suatu prinsip tanggung jawab bersifat subjektif yaitu suatu tanggung jawab yang ditentukan oleh prilaku pengusaha pariwisata. Sifat subjektifitas muncul pada kategori bahwa seseorang bersikap hati - hati mencegah timbulnya kerugian pada para wisatawan.

Berdasarkan teori tersebut, kelalaian para pengusaha pariwisata yang berakibat munculnya suatu kerugian terhadap para wisatawan merupakan faktor penentu adanya hak para wisatawan untuk mengajukan tuntutan kerugian kepada para pengusaha pariwisata. Dalam Danang Sunyoto $(2015: 143)$ disamping faktor kesalahan dan kelalaian para pengusaha pariwisata tersebut, tuntutan ganti rugi berdasarkan kelalaian diajukan berdasarkan pada bukti - bukti, yaitu:

a. Pihak tergugat yang terdiri dari para pengusaha pariwisata benar - benar mempunyai kewajiban untuk melakukan tindakan yang dapat menghindari terjadinya kerugian para wisatawan;

b. Para pengusaha pariwisata tidak melaksanakan kewajiban untuk menjamin kualitas produk/jasanya dipasarkan sesuai dengan standar yang aman untuk dikonsumsi atau digunakan;

c. Para wisatawan penderita kerugian.

Kelalaian para pengusaha pariwisata merupakan faktor yang mengakibatkan adanya kerugian pada para wisatawan (hubungan sebab akibat antara kelalaian dan kerugian para wisatawan). Dalam prinsip tanggung jawab berdasarkan kelalaian juga mengalami perkembangan dengan tingkat tanggungjawab yang berbeda terhadap kepentingan para wisatawan, yaitu:

1) Tanggungjawab Atas Kelalaian Dengan Persyaratan Hubungan Kontrak

Teori murni prinsip tanggung- jawab berdasarkan kelalaian adalah suatu tanggungjawab yang didasarkan pada adanya unsur kesalahan dan hubungan kontrak. Teori ini sangat merugikan para wisatawan karena gugatan baru dapat diajukan jika telah memenuhi dua syarat, yaitu adanya unsur kesalahan atau kelalaian dan hubungan kontrak antara para pengusaha pariwisata dan para wisatawan. Teori tanggungjawab produk berdasarkan kelalaian tidak memberikan perlindungan yang maksimal kepada para wisatawan, karena wisatawan dihadapkan pada dua kesulitan dalam mengajukan gugatan kepada para pengusaha pariwisata yaitu, pertama, tuntutan adanya hubungan kontrak antara para wisatawan sebagai penggugat dengan para pengusaha pariwisata sebagai tergugat. Kedua, argumentasi para pengusaha pariwisata bahwa kerugian para wisatawan diakibatkan oleh kerusakan barang yang tidak diketahui.

2) Kelalaian Dengan Beberapa Pengecualian Terhadap Persyaratan Hubungan Kontrak

Perkembangan tahap kedua teori tanggung jawab berdasarkan kelalaian adalah prinsip tanggung jawab yang tetap berdasarkan kelalaian namun untuk beberapa kasus terdapat pengecualian terhadap persyaratan kontrak. Seperti yang telah disebutkan sebelumnya, bahwa persyaratan hubungan kontrak merupakan salah satu hambatan wisatawan untuk mengajukan ganti kerugian kepada para pengusaha pariwisata. Prinsip ini tidak memihak kepada kepentingan wisatawan, karena pada kenyataannya wisatawan yang sering mengalami kerugian atas pemakaian suatu produk/jasa adalah wisatawan yang tidak memiliki kepentingan hukum dengan para pengusaha pariwisata.

3) Kelalaian Tanpa Persyaratan Hubungan Kontrak

Setelah prinsip tanggung jawab atas dasar kelalaian dengan beberapa pengecualian terhadap hubungan kontrak sebagai tahap kedua dalam 
perkembangan substansi hukum tanggung jawab produk/jasa, maka tahap berikutnya adalah tahap ketiga yaitu sistem tanggung jawab yang tetap berdasarkan kelalaian, tetapi sudah tidak mensyaratkan adanya hubungan kontrak.

4) Prinsip praduga lalai dan prinsip Bertanggung Jawab dengan Pembuktian Terbalik

Tahap perkembangan terakhir dalam prinsip tanggung jawab berdasarkan kelalaian adalah dalam bentuk modifikasi terhadap prinsip tanggung jawab berdasarkan kesalahan. Dalam Danang Sunyoto, 2015:146 menyatakan bahwa modifikasi ini bermakna, adanya keringanan - keringanan bagi wisatawan dalam penerapan tanggung jawab berdasarkan kelalaian, namun prinsip tanggung jawab ini masih berdasarkan kesalahan. Modifikasi ini merupakan masa transisi menuju pembentukan tanggung jawab yang mutlak.

2. Prinsip Tanggung Jawab Berdasarkan Wanprestasi

Selain mengajukan gugatan terhadap kelalaian para pengusaha pariwisata, ajaran hukum juga memperkenalkan para wisatawan untuk mengajukan gugatan atas wanprestasi. Tanggung jawab pengusaha pariwisata yang dikenal dengan wanprestasi adalah tanggung jawab berdasarkan kontrak. Ketika suatu produk/ jasa rusak dan mengakibatkan kerugian, para wisatawan biasanya melihat isi kontrak atau perjanjian yang merupakan bagian dari kontrak, baik dalam bentuk tertulis maupun lisan.

Keuntungan para wisatawan dalam gugatan berdasarkan teori ini adalah penerapan kewajiban bersifat mutlak, yaitu suatu kewajiban yang tidak didasarkan pada upaya yang telah dilakukan pengusaha pariwisata terhadap janjinya. Itu berarti apabila pengusaha pariwisata telah berupaya memenuhi janjinya tetapi para wisatawan tetap menderita kerugian, maka pengusaha pariwisata tetap dibebani tanggung jawab untuk mengganti kerugian.

Dalam prinsip tanggung jawab berdasarkan wanprestasi terdapat beberapa kele- mahan yang dapat mengurangi bentuk perlindungan hukum terdapat kepentingan para wisatawan, yaitu: (a) pembatasan waktu gugatan; (b) persyaratan pemberitahan; (c) kemungkinan adanya bantahan; dan (d) persyaratan hubungan kontrak, baik hubungan kontrak secara horizontal maupun vertikal.

\section{Prinsip Tanggung Jawab Mutlak}

Azas tanggung jawab ini dikenal dengan nama product liability. Menurut prinsip ini, para pengusaha pariwisata wajib bertanggung jawab atas kerugian yang diderita oleh para wisatawan atas penggunaaan produk/jasa yang dipasarkan. Tanggung jawab mutlak strict liability, yakni unsur kesalahan tidak perlu dibuktikan oleh pihak para wisatawan sebagai dasar ganti kerugian, ketentuan ini merupakan lex specialis dalam gugatan tentang melanggar hukum pada umumnya.

Para wisatawan yang bertindak sebagai konsumen hanya perlu membuktikan adanya hubungan klausalitas antara perbuatan para pengusaha pariwisata dan kerugian yang dideritanya. Dengan diterapkannya prinsip tanggung jawab ini, maka setiap wisatawan yang merasa dirugikan akibat produk/jasa cacat atau tidak aman dapat menuntut konpensasi tanpa harus mempermasalahkan ada atau tidaknya unsur kesalahan dipihak pengusaha pariwisata.

Alasan mengapa prinsip tanggung jawab mutlak diterapkan dalam hukum tentang product liability ini, adalah:

1. Para wisatawan sebagai sebagai konsumen menjadi korban di satu pihak dan ada pengusaha pariwisata di lain pihak, beban kerugian seharusnya ditanggung oleh pihak yang membuat suatu produk/jasa.

2. Dengan menjual produk/jasa dipasaran, berarti mereka menjamin bahwa produk - produk/jasa yang dipasarkan tersebut aman dan pantas untuk digunakan, bilamana terbukti tidak demikian dia harus bertanggung jawab.

\subsection{Hak dan Kewajiban Wisatawan Pasca Berlakunya Peraturan Daer- ah Propinsi Bali No.2 Tahun 2012}

Di era globalisasi,hak dan kewajiban para pengguna jasa pariwisata baik wisatawan domestik maupun manca negara serta para pengusaha pariwisata sangat dibutu- 
hkan.Secara yuridis produk hukum yang dapat dicermati terkait dengan pengaturan hak dan kewajiban sebagai perlindungan hukum terhadap para wisatawan adalah Undang- Undang No. 10 Tahun 2009 tentang Kepariwisataan, Undang- Undang No. 8 Tahun 1999 Tentang Perlindungan Konsumen dan Peraturan Daerah Propinsi Bali No.2 Tahun 2012 Tentang Kepariwisataan Budaya Bali.

Ketentuan Pasal 20 huruf c dari Undang- Undang No.10 Tahun 2009 menyatakan bahwa setiap wisatawan berhak memperoleh perlindungan hukum dan keamanan. Secara eksplisit hak wisatawan untuk mendapatkan perlindungan hukum diatur dalam ketentuan Pasal 20 huruf c undang - undangkepariwisataan ini. Pihak pengusaha pariwisata, menurut ketentuan Pasal 26 ayat (d) berkewajiban memberikan kenyamanan, keramahan, perlindungan keamanan dan keselamatan wisatawan. Selain itu, pemerintah dan pemerintah daerah menurut ketentuan Pasal 23 ayat (1) huruf a, berkewajiban menyediakan informasi kepariwisataan, perlindungan hukumserta keamanan dan keselamatan kepada para wisatawan.

Selain dalam Undang- Undang No. 10 Tahun 2009 Tentang Kepariwisataan, di mana perlindungan hukum terhadap hakhak wisatawan sebagai konsumen diatur pula dalam Pasal 26 ayat (4) Peraturan Daerah Propinsi Bali No.2 Tahun 2012. Dalam Pasal ini disebutkan bahwa setiap wisatawan berhak memperoleh:

a. Informasi yang akurat mengenai daya tarik wisata;

b. Fasilitas umum dan pelayanan kepariwisataan sesuai dengan standar;

c. Perlindungan keamanan dan kenyamanan termasuk menyediakan fasilitas bagi wisatawan usia lanjut dan pnyandang cacat;

d. Pelayanan pertolongan pertama pada kecelakaan (P3K); dan

e. Jaminan asuransi untuk kegiatan pariwisata yang beresiko tinggi.

Disamping adanya hak para wisatawan untuk mendapatkan apa yang menjadi haknya namun bagi mereka terlibat dalam pembangunan kepariwisataan seperti pengusaha pariwisata juga memiliki hak sama. Hak para pengusaha pariwisata ini seperti disebutkan dalam Peraturan Daerah Propinsi Bali No.2 Tahun 2012 Tentang
Kepariwisataan Budaya Bali khususnya dalam ayat (5) yang menyatakan setiap pengusaha pariwisata, berhak:

a. Mendapatkan kesempatan yang sama dalam berusaha di bidang kepariwisataan;

b. Membentuk dan menjadi anggota asosiasi kepariwisataan;

c. Mendapatkan perlindungan hukum dalam berusaha; dan

d. Mendapatkan fasilitas sesuai dengan peraturan perundang - undangan.

Disamping hak - hak yang telah disebutkan diatas bahwa seorang wisatawan juga memiliki beberapa kewajiban agar pembangunan kepariwisataan budaya dapat berjalan dengan baik. Daya tarik wisata yang ada harus dijaga kelestariannya disamping mampu menciptakan suasana aman, tertib, bersih dan setiap orang harus mampu bersikap sopan santun terhadap orang lain. Oleh karena itu, setiap wisatawan memiliki beberapa kewajiban sesuai yang disebutkan dalam Peraturan Daerah Propinsi Bali No.2 Tahun 2012 khususnya dalam Pasal 27 ayat (2), diantaranya:

a. Menghormati norma agama, adat istiadat, budaya dan nilai - nilai yang hidup dalam masyarakat setempat;

b. Memelihara dan melestarikan lingkungan;

c. Tutur serta menjaga ketertiban dan keamanan lingkungan; dan

d. Tidak melakukan perbuatan yang melanggar kesusilaan.

Disamping adanya hak - hak yang mesti diperoleh oleh wisatawan dan pengusaha pariwisata, disisi lain mereka juga memiliki suatu kewajiban agar diperoleh suatu keseimbangan dan keselarasan hidup dalam melakukan aktifitas wisata. Dalam Pasal 27 ayat (2) Peraturan Daerah Propinsi Bali No.2 Tahun 2012Tentang Kepariwisataan Budaya Bali, disebutkan setiap wisatawan, harus:

a. Menghormati norma agama, adat istiadat, budaya dan nilai - nilai yang hidup dalam masyarakat setempat;

b. Memelihara dan melestarikan lingkungan;

c. Turut serta menjaga ketertiban dan keamanan lingkungan; dan

d. Tidak melakukan perbuatan yang melanggar kesusilaan.

Tidak hanya wisatawan saja yang memiliki kewajiban agar kepariwisataan 
budaya Bali dapat berjalan dengan baik. Diharapkan pada semua orang yang terlibat dalam pembangunan kepariwisataan budaya ini terutamanya pengusaha pariwisata juga memiliki kewajiban yang sama. Dalam Pasal 27 ayat (3) peraturan daerah ini disebutkan bahwa setiap pengusaha pariwisata, wajib:

a. Melestarikan kebudayaan Bali, menjaga dan menghormati norma agama, adat istiadat, budaya dan nilai - nilai yang hidup dalam masyarakat setempat;

b. Membangun sarana kepariwisataan dengan langgam arsitektur Bali atau sekurang - kurangnya diperindah dengan menonjolkan ciri - ciri seni budaya daerah Bali, tata ruang dan komponen - komponennya;

c. Memberikan informasi yang akurat dan bertanggung jawab;

d. Memberikan pelayanan yang tidak diskriminatif;

e. Memberikan kenyamanan, keramahan, perlindungan keamanan dan keselamatan wisatawan;

f. Memberikan jaminan asuransi kepada wisatawan dan tenaga kerja yang melaksanakan kegiatan wisata beresiko tinggi;

g. Mengembangkan kemitraan dengan usaha mikro, kecil dan koperasi setempat yang saling memerlukan, memperkuat dan menguntungkan;

h. Mengutamakan penggunaan produk masyarakat setempat, terutama hasil komoditas pertanian dan produk dalam negeri;

i. Meningkatkan kompetensi tenaga kerja melalui pelatihan, pendidikan dan sertifikasi;

j. Berperan aktif dalam program pemberdayaan masyarakat;

k. Mencegah segala bentuk perbuatan yang melanggar kesusilaan dan kegiatan yang melanggar hukum di lingkungan tempat usahanya;

1. Memelihara lingkungan yang sehat, asri dan bersih;

m. Memelihara kelestarian lingkungan alam dan budaya;

n. Menjaga citra daerah dan masyarakat melalui kegiatan usaha pariwisata yang bertanggung jawab; dan

o. Menerapkan standar usaha dan standar kompetensi sesuai dengan ketentuan peraturan perundang - undangan.

Sedangkan dalam ayat (4) peraturan daerah ini disebutkan bahwa pengelola daya tarik wisata juga diwajibkan, untuk:

a. Memelihara, mengembangkan dan mempromosikan produk dan daya tarik wisata berdasarkan falsafah Tri Hita Karana;

b. Mencegah terjadinya gangguan, pencemaran dan perusakan daya tarik wisata; dan

c. Menjamin dan mengutamakan kenyamanan wisatawan.

Berangkat dari pemikiran diatas sehingga Undang- Undang No. 10 Tahun 2009 dan Peraturan Daerah Propinsi Bali No. 2 Tahun 2012 dapat dijadikan rujukan untuk melindungi dan mengatur hak dan kewajiban para wisatawan serta pengusaha pariwisata. Menurut Violetta Simatupang (2009), perlindungan terhadap wisatawan harus dipertahankan, sebab tanpa hal itu wisatawan cenderung tidak akan memilih negara Indonesia sebagai negara tujuan wisata. Bila hal ini terjadi, maka akan berdampak buruk bagi perkembangan kepariwisataan Indonesia dan daerah Bali pada khususnya.

Propinsi Bali memang merupakan daerah tujuan wisata dunia yang sangat dikenal oleh para wisatawan domestik maupun manca negara. Saat ini daerah Bali sedang membangun sektor kepariwisataan berlandaskan pada nilai - nilai agama dan kebudayaan lokal. Kebudayaan lokal Bali inilah dijadikan pilar pembangunan kepariwisataanya.Julukan daerah Bali sebagai daerah pariwisata budaya memang pantas disandangnya. Dengan berbagai macam jenis kebudayaan yang dimilikinya sehingga hampir semuatempat dapat dijadikan pusat destinasi kepariwisataan budaya Bali.

\subsection{Simpulan}

\section{PENUTUP}

1. Perlindungan hukum adalah suatu perlindungan yang diberikan kepada setiap orang sesuai dengan aturan hukum, baik aturan itu yang bersifat preventif maupun bersifat represif, baik secara tertulis maupun tidak tertulis dalam rangka penegakan peraturan hukum.

2. Setiap pengusaha pariwisata secara prinsip harus mampu menciptakan rasa aman dan nyaman terhadap se- 
tiap wisatawan. Setiap orang mesti mendapatkan perlakuan dan dipandang sama di mata hukum (equlity before the law).

3. Setiap orang memiliki hak yang sama untuk memperoleh kesempatan memenuhi kebutuhan wisata dan kewajiban agar menjaga dan melestarikan setiap daya tarik wisata untuk terciptanya rasa aman, tertib, bersih dan menjaga kelesstarian lingkungan.

\subsection{Saran}

1. Perlindungan hukum harus dapat dilakukan dengan secara preventif agar tidak menimbulkan adanya kerugian yang lebih besar pada semua pihak.

2. Setiap pengusaha pariwisata harus mampu memandang setiap wisatawan sama dalam setiap aktifitas paiwisatanya tanpa membedakan tinggi rendahnya status wisatawan.

3. Setiap orang harus diberikan hak dan kewajiban yang sama dalam berwisata tanpa adanya diskriminasi yang berlebihan.

\section{DAFTAR PUSTAKA}

Hadion Wijoyo,"Problematika Hukum di Bidang Investasi dalam Era Otonomi Daerah".Jurnal Hukum Republica,Vol. 5, No. 2, Tahun 2006, hlm.162

Hetty Hasanah,2004, "Perlindungan Konsumen dalam Perjanjian Pembiayaan Konsumen atas Kendaraan Bermotor dengan Fidusia",Jurnal Unikom, Vol, diakses pada web site :http//jurnal.unikom.ac.id/vol3/perlindungan, html., hlm. 1.

I Gede Pitana dan I Ketut Surya Diarta, 2009, Pengantar Ilmu Pariwisata, Jogjakarta, Andi, hlm. 2.

I Putu Gelgel, 2009, Industri Pariwisata Indonesia Dalam Globalisasi Perdagangan Jasa (GATS-WTO) Implikasi Hukum dan Implementasi Hukumnya, Bandung, Refika Aditama.
Ismiyanti, 2010, Pengantar Pariwisata, Jakarta, Grasindo Widiasarana Indonesia

Made Metu Dhana, 2012, Perlindungan Hukum dan Keamanan Terhadap Wisatawan, Surabaya, Paramita.

Muljadi, 2012, Kepariwisataan dan Perjalanan, Jakarta,Raja Grafindo Persada.

Mardani, 2003, Dalam Pariwisata Budaya Berkelanjutan, Refleksi dan Harapan Di Tengah Perkembangan Global, Program Magister (S2) Kajian Pariwisata, Program Pascasarjana Universitas Udayana,Denpasar, hlm.73.

Oka A Yoety, 2009, "Industri Pariwisata dan Peluang Kesempatan Kerja, Jakarta: PT Pertja, hlm. 1

Peraturan Daerah Bali Nomor 2 Tahun 2012 Tentang Kepariwisataan $\mathrm{Bu}-$ daya Bali

Suparman Khan, 2001, “Apresiasi Hak Asasi Manusia Dalam Rangka Demokratisasi di Indonesia", Jurnal Jurisprudentia Vol. 1 No. 1I, hlm. 95

Undang-Undang Republik Indonesia No. 10 Tahun 2009 Tentang Kepariwisataan

Undang-Undang Republik Indonesia No. 8 Tahun 1999 Tentang Perlindungan Konsumen.

Violetta Simatupang, 2009, "Pengaturan Hukum Kepariwisataan Indonesia", PT. Alumni, Bandung.

Wahyu Sasongko, Ketentuan - Ketentuan Pokok Hukum Perlindungan Konsumen, Unila, Lampung,2007. hlm. 31 